\title{
A review on optimal placement and sizing of custom power devices/FACTS devices in electrical power systems
}

\author{
V. Tejaswini, D. Susitra \\ Electrical Enigineering, Sathyabama Institute of Science and Technology, India.
}

\begin{tabular}{l}
\hline Article Info \\
\hline Article history: \\
Received Sep 6, 2018 \\
Revised Nov 19, 2018 \\
Accepted Feb 15, 2019 \\
\hline
\end{tabular}

Keywords:

Custom power devices/FACTS devices,

D-STATCOM,

Location and sizing,

Power system netork,

SVC,

TCSC.

UPQC,

\begin{abstract}
Power loss reduction, improvement of voltage profile, system reliability and system security are the important objectives that motivated researchers to use custom power devices/FACTS devices in power systems. The existing power quality problems such as power losses, voltage instability, voltage profile problem, load ability issues, energy losses, reliability problems etc. are caused due to continuous load growth and outage of components. The significant qualities of custom power devices /FACTS devices such as power loss reduction, improvement of voltage profile, system reliability and system security have motivated researchers in this area and to implement these devices in power system. The optimal placement and sizing of these devices are determined based on economical viability, required quality, reliability and availability. In published literatures, different algorithms are implemented for optimal placement of these devices based on different conditions. In this paper, the published literatures on this field are comprehensively reviewed and elaborate comparison of various algorithms is compared. The inference of this extensive comparative analysis is presented. In this research, Meta heuristic methods and sensitive index methods are used for determining the optimal location and sizing of custom power devices/FACTS devices. The combination of these two methods are also implemented and presented.
\end{abstract}

Copyright ( 2019 Institute of Advanced Engineering and Science. All rights reserved.

\section{Corresponding Author:}

V.Tejaswini,

Electrical Enigineering,

Sathyabama Institute of Science and Technology (Deemed to be University),

Chennai. Tamilnadu, India.

Email: tejusateeshkumar@gmail.com

\section{INTRODUCTION}

In recent years, due to increasing load demand of electricity, the sizing and complexity of electric power systems are highly increased. Therefore a stable, reliable and uninterrupted power quality with the minimum power losses is a very different task in power systems [1]. Increasing load demand may lead to voltage instability in buses and excessive power flows in branches [2]. Moreover, because of outage of components there may be a chance of power congestion, static and dynamic instabilities [3]. To compensate power losses and maintain voltages within the limit series voltage regulators and shunt capacitors are used, but these two devices having some disadvantages that are series voltage regulators operates in step by step manner so that it have slow response and it can't generate reactive power. Shunt capacitors can't generate continuous reactive power, so to compensate these drawback power electronic based custom power devices/FACTS devices are used in power systems [4]. Generally custom power devices, which are nearly same as FACTS devices, this are used to solve problems like power interruption and poor power quality in power system network. However custom power devices and FACTS devices are share a common technical base, these devices have different performance results. The FACTS devices are used in the transmission 
system, while custom power devices are used in distribution [5]. Custom power devices are especially effective in the system reliability and power quality.

Custom power devices/FACTS devices having high installation cost, however these devices are used in both transmission and distribution systems because of the better performance of these devices, in view of this it is necessary to determine the optimal placement of Custom Power devices/FACTS devices [6]. Custom power devices/FACTS devices are more effective devices to minimize power losses, voltage stability margin enhancement, cost of energy savings, improving reliability and security of the power system. FACTS devices are DVR, DSTATCOM, UPQC, UPFC, SVC etc. There exist less research work on optimal location and sizing of custom power devices in the distribution system rather than research work on optimal placement of FACTS devices in the transmission systems [7]. Figures $1 \& 2$ shows the representation of Custom Power Devices/FACTS devices in power system. This paper presents metahuristic methods for distribution and transmission system, further sensitivity index methods are reviewed in detail. Finally an overall review will represented for future research will be suggested.

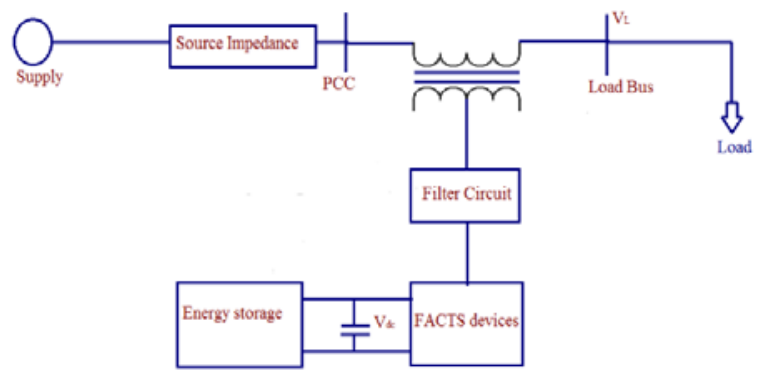

Figure 1. Optimal placement of FACTS devices in transmission systems

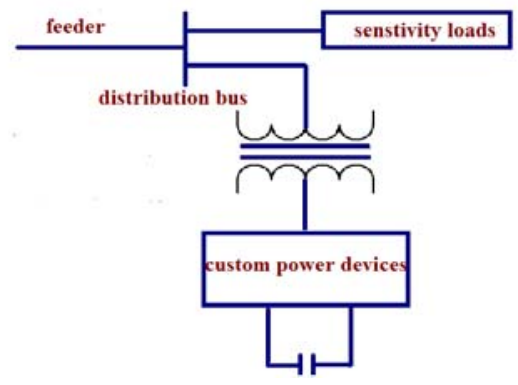

Figure 2. Optimal placement of costum power devices in distribution systems

\section{REVIEW OF RESEARCH ON CUSTOM POWER/FACTS DEVICES ALLOCATION:}

All existing methods for optimal allocation of Custom power/FACTS devices can be divided in to categories. Meta-heuristic methods, sensitivity index methods and Combination of sensitivity approach and meta-heuristics.

\subsection{Meta-heuristic methods}

These methods are efficient and flexible methods. Discrete and constraint optimization problems can be easily solved by using Meta-heuristic approaches [8]. Problems related to multimodal, multi objective functions can also be solved by using these methods.

\subsubsection{Algorithms for transmission systems}

In [9] Jan 2019, P. Lokender Reddy, G. Yesuratnam interdicted modified Bacterial foraging algorithm for optimal reactive power dispatch problem. The main objective functions are minimization of real power loss and voltage stability L-index this method is tested on IEEE 30 bus system. In [10] Dec 2018, Salman and Ali used genetic algorithm to determine the optimal location and sizing of UPFC. The main objective functions are voltage profile improvement, power losses reduction, treatment of power flow in 
overloaded transmission lines and minimize total cost of power system. In [11] Aug 2018, Sirote Khunkitti, Apirat Siritaratiwat Proposed Hybrid DA-PSO Optimization Algorithm to solve multi objective optimal power flow (OPF) problems in a power system. This new hybrid DA-PSO algorithm provides exploration phase of DA and the exploitation phase of PSO, to improve its performance for finding solution of the OPF problems. The main objective is to minimize fuel cast and transmission losses.

In [12] Sep 2016, Elazim and Ali used Cuckoo search algorithm to find optimal location of STATCOM in multi mission power system. It is inspired from life of bards. By using STATCOM the overall voltage profile and system load ability can be improved. PV curves are used to determine location of STATCOM and CS algorithm is used to solve optimization problems. Compare to GA, CS provides good damping characters to the system oscillations over a wide range of loading conditions. In [13] 2016, Sai Ram and Venkanna implemented PSO adaptive GSA hybrid algorithm and it is used to find the optimal location, power ratings of the FACTS devices based on voltages and minimum power losses. Gravitational constants are optimized by using PSO algorithm to improve the searching performance of the GSA. UPFC \& IPFC are used for system stability analysis. Voltage, power loss values can be calculated by placing IPFC in between two busses and magnitudes of voltage, power loss can be evaluated by placing UPFC in between two busses. PSO-GSA provides better stability margin and reducing power losses compare to GA \& GSA. In [14] March 2016, Susanta and Roy developed chemical reaction optimization for optimal location of STATCOM, in order to solve optimal reaction power dispatch problems. STATCOM can minimize transmission losses and voltage deviations and improves voltage profile, voltage stability of the system. This CRO method is more efficient than PSO and DE.

In [15] 2016, Imperialistic competitive algorithm inspired form socio-political phenomenon of imperialistic computation is used for optimal design of STATCOM in power systems. Optimization problems can be solved by using IC. The proposed ICA STATCOM provides good damping characteristic to the system oscillations and also improves overall voltage profile, system load ability. In [16] 2015, Rezaee Jaordehi developed Brainstorm optimization algorithm for optimal placement of FACTS devices, it is heuristic algorithm, which is inspired from Brainstorming process in human being. SVC and TCSC devices are used for voltage profile enhancement, over load minimization and loss reduction. Compare to enhancement GA, PSO and DE, this BSOA provides better voltage profile and less power losses. In [17] 2014, Thanh long, Jian used mini cut algorithm for finding the location, quantity and size of TCSC. It improves system loadability through changing line reactance by installing the TCSC on transmission line. This method improves system loadability, minimize the installation cost and reduce search space. This will be tested on IEEE 6 bus, 13 bus, and 118 bus systems.

In [18] Sep 2013, Edward and Rajasekar proposed an enhanced bacterial foraging algorithm to determine suitable location and sizing for SVC and TCSC devices, in order to minimize power flow problems enhanced EBFA is combination of BF and Nelder-Mead algorithm so it is called as hybrid algorithm. Compare BF, EBF provides better optimal parameter selection, reduces the generation cost and improves voltage stability limit. In [19] 2013, Safari and Ahmadaian proposed honey bee mating optimization algorithm for optimal design of STATCOM. It is inspired from birds' life. This proposed method provides good damping characteristics to low frequency oscillations and improves system stability.

In [20] 2011, ES ali and S.M abd Elazin;intro introduced an improved bacterial swarm optimization algorithm for coordinated design of PSSs and TCSC in a multi machine power system. This BSO is hybrid algorithm and it is combination of BF and PSO. Over a wide range of load conductions the coordinated design problems of PSS \& TCSC is excited, that problem consider as optimization problem. BSO provides better damping characteristics to system oscillations over wide range of load conductions and different disturbances. When compare to BF \& PSO, BSO provides faster and more efficient convergence, prevent trappings in local areas.

\subsubsection{Algorithms for distribution Systems}

In [21] Apr 2019, Srider and Prakash proposed whale optimization algorithm for finding optimal location and sizing of the DG. Main objective function is minimization of power loss and cost with maximum voltage stability index, this method is tested for IEEE 69 bus system. In [22] Feb 2018, M. Laxmidevi Ramanaiah, M. Damodar Reddy introduces moth flame optimization method to determine the optimal location of UPQC in distribution system. In large distribution systems UPQC's steady state compensation capability has given a solution for providing reactive power compensation. Main objectives are to real power loss reduction, voltage profile improvement. In [23] Nov 2017, Laxmi \& Damodar used Gray Wolf optimization for optimal allocation of UPQC in Distribution system. This gray wolf optimization inspired by the hunting mechanism of grey wolves. The main objective function is to reduce power loss and voltage profile improvement of the system. This can be tested on standand IEEE 33 and 69 bus systems.

Int J Pow Elec \& Dri Syst, Vol. 10, No. 2, June 2019: 900 - 908 
In [24] another research work 2015, harmony search algorithm is used to find optimal location \& sizing of DSTATCOM. This algorithm is inspired from improvisation process in music. The main objective is to minimize total power losses. This method is tested on IEE-33 bus system. Harmony algorithm will reduce power losses more than immune algorithm. In [26] 2014 Devi and Gethanjali introduced PSO for finding the optimal location and sizing of DG and DSTATCOM , in order to reduce power losses \& improve voltage profile.PSO is inspired by fish schooling and bird flocks. The study is done with five different cases. In all cases performance of DG\&DSTATCOM can be analyzed by using LSF method. In [27] 2014 taher, Afsari used immune algorithm for optimization problems of DSTATCOM in radial distribution system. It reduces power losses, cost of DSTATCOM and improve voltage of buses. Compare to GA, IA provides minimum DSTATCOM size and CPU time.

In [28] 2013, Masoud and Azah used firefly algorithm to find optimal location and sizing of DSTATCOM in distribution system, for power quality enhancement. A newly defined objective function is interdicted, which include total harmonic distortion, voltage deviations and total investment cost of DSTATCOM. This firefly algorithm provides better results than GA and PSO. In [29] 2012, Abas and Afsari used Differential evaluation algorithm to determine optimal location of UPQC considering its size. In the radial distribution system, Objective function defined for voltage and current profile improvement, power loss reduction, minimization of investment cost. Compared with IA and GA, DC converges faster \& smother, it provides minimum UPQC size, CPU time and objective function.

\subsection{Sensitive approach}

In sensitive approach or method, first an index is explained and computation for different potential locations of Custom power devices/FACTS devices determined based on the computed indices, most commonly two types of indices are used for allocation problems those indices are voltage sensitivity index, power loss index.

\subsubsection{Voltage sensitivity index}

To determine optimal location of Custom power devices/FACTS devices, voltage stability index (VSI) is calculated for different buses, the bus which is having highest VSI value then that bus chosen for custom power devices/FACTS device placement.

a) Algorithms for Transmission Systems

In [30] 2016,mutegi \& Kihato proposed a voltage stability based method to find optimal placement of FACTS devices in the weak \& heavily loaded buses for voltage stability improvement two voltage stability indices, namely the Fast voltage stability index \& the line stability index are used to determine best location of FACTS devices. In [31] 2015, Albast\& Ahmad Proposed, voltage sensitivity based method is used to determine optimal location of UPQC for security constrained voltage stability improvement. Initially the voltage stability of all buses was determined by calculating voltage collapse proximity indicates (VCPI), VSI \& LLSI values and most unstable bus was selected for UPFC placement. 39 bus systems is used for testing of results. Placement of unified power flow controllers to improve dynamic voltage stability using power system variable based voltage stability indices. In [32] 2014, nurdin and fathin proposed sensitivity analysis for placement of shunt DVR compensator \& STATCOM in the power system. Reactive power losses can be reduced by using STATCOM and voltage instability can be prevented by using shunt DVR compensators. Three sensitivity indices are used namely, voltage stability index, voltage sensitivity index, angle sensitivity index to select best bus locations for shunt DVR compensator and STATCOM.

b) Algorithms for Distribution System

In [33] 2018, Bushra Weqar, Mohd Tauseef Khan used voltage stability index and loss sensitivity factor, to determine the optimal location and size of DG and DSTATCOM. This is tested on 33-bus radial distribution system. changes in voltage profile and active power losses were compared before and after installation of these devices. Optimal placement of DG, DSTATCOM reduces the power losses and improves the voltage profile. In [34] 2015, Penkita Mehta, Praghnesh Bhatta presents the analysis for selection of the best D.G units from different categories in Distribution systems for voltage stability improvement and loss reduction. Voltage stability indices are used to investigate the impact of location D.G units for the power losses, voltage profile and voltage stability. In [35] 2014 Jain and Gupta used voltage sensitivity index for determine the optimal placement of DSTATCOM to enhance the voltage profile \& reduce power losses. First voltage stability index values should calculate for all buses, in order to determine unstable bus for placement of DSTATCOM. Finally the results have been presented for IEEE 33 bus system. In [36] 2012 Hussain and Visali proposed a voltage sensitivity based method for determine the weakest bus of distribution network. Voltage profile is improved by placing DSTATCOM on the weakest bus. The efficiency of the proposed VSI have been tested on IEEE 33 bus system. 


\subsection{Power loss index}

Power loss index (PLI) is another approach to select suitable location for custom power devices/FACTS devices, power loss are calculated based on load flow studies. At all nodes except for source node, reactive power is injected, and the total power losses \& loss reduction at each node are calculated. The node which is having highest value of PLI, that node will be the best place for installation of custom power device/FACTS devices.

a) Algorithms for Transmission System

In [37] April 2018, loss sensitivity indices are used for placement of TCSC and TCPAR devices. The objective function is minimization of line losses this approach is implemented on IEEE 57-bus system. In [38], 2017, another research work, power loss sensitivity index is used to determine optimal placement pf STATCOM then optimal parameters setting of STATCOM has been done by Newton Raphson power flow technique. The objective function is minimization of system power losses, this approach is implemented on 14 bus test system, before and after placing the STATCOM, voltage and power losses have been compared. In [39] 2013, Manikandan and Arul proposed power loss index method to determine optimal placement of TCSC and UPFC, for controlling power loss and enhancing the usable capacity of transmission line. Two indices are used namely power loss sensitivity index and sensitivity of over loadability index (SOL).

b) Algorithms for Distribution System

In [40] march 2017, Fahad, Mohd khan introduced new methodology for finding optimal placement of DG and DSTATCOM for loss reduction and voltage profile improvement. Loss sensitivity factor (LSF) used for finding the best location of DG. All the operational and system constraints must be considered and verified to find the optimal location of DSTATCOM. Optimal size of DG and DSTATCOM can be determined by using direct load flow analysis. In [41] 2016 Atma Ram Gupta, Ashwari kumar proposed “ performance analysis of Radial Distribution with UPQC \& DSTATCOM. Proposed power loss index method for finding optimal location of DSTATCOM \& UOQC in radial distribution system. The bus which is having the minimum losses, that bus is selected as the candidate bus for UPQC placement and optimal location of DSTATCOM is found by PLT. The main objective is to reduce power losses, investment cost and improving voltage profile of the system.

In [42] 2016 Gupta and Kumar proposed sensitivity indices for optimal location of D-STATCOM's. fast voltage stability index, the combined power loss index, voltage stability index, voltage sensitivity index and proposed stability index are used. The new voltage sensitivity index is used to determine the optimal location of D-STATCOM. Optimal size of D-STATCOM found in summer and winter times, consider load improvement. the efficiency of different sensitivity-based approaches in optimal allocation of D-STATCOM's were compare, and the impact of the optimal placement of D-STATCOM's to improve voltage stability margin, reduce energy losses and increase energy cost savings were investigated.

In [43] 2015, power loss index method is used for placement of DSTATCOM in radial distribution system for reduction of line losses and improvement of voltage profile. Bus parameters can be calculated by using load flow methods. Mathematical modeling is used to calculate reactive power injection of DSTATCOM for all he buses. Based on reactive power values optimal location of DSTATCOM can be selected by using PLI.

\subsection{Combination of meta-heuristic \& sensitivity approach}

In some research work, sensitivity index methods and meta-heuristic techniques has been hybridized and applied to custom power devices/FACTS devices allocation problems to get better solutions compared to individual methods.

a) Algorithms for Transmission System

In [44] Feb 2018, Sravana kumar, Suryakalavathi proposed a new method for optimal placement of TCSC \& optimal tuning of generators in power system. Combined index is used for optimal generator reallocation with optimal placement of TCSC. Krill Herd algorithm is used for optimal tuning of TCSC. Combined index having line utilization factor (LUF) and fast voltage stability index (FVSI). The main objective function is minimization of line loss and voltage deviation. In [45] 2015, gravitational search algorithm is presented to determine the optimal placement of FACTS devices (TCSC, SVC, UPFC). Voltage security index (VSI), line security index (LSI) are used for performance analysis. The main aim is to reduce power losses and enhancement of system security. In [46] 2012, a new method is proposed for optimal placement of TCSC and STATCOM in power system. Real power flow sensitivity index and combination voltage sensitivity index are used for finding optimal placement of TCSC and STATCOM. The optimal rating of TCSC and best sizing of STATCOM is optimized by using the Genetic algorithm. The objective function is to reduce severity of the system loadings and enhancement of voltage stability of the system.

In [47] 2009, Parizad and Khazali proposed heuristic methods and sensitivity index for optimal placement of FACTS devices. HSA and GA have used to determine optimal location of TCPAR, UPFC and

Int J Pow Elec \& Dri Syst, Vol. 10, No. 2, June 2019: 900 - 908 
SVC devices. For system analysis, Three different cases are considered: 1) TCPAR, UPFC, SVC are placed individually 2) any two devices placed randomly 3) three devices are placed simultaneously. In all three cases voltage indices and losses should be calculated to select the better places for the devices. The main objective function is to improve voltage profile, reduce power losses, increasing power transfer capacity, maximum loading and voltage stability margin.

b) Algorithms for Distribution System

In [48] Nov 2018, Selva Raj, Rajangam introduced multi objective modified flower pollination algorithm (Mo-MFPA) for power loss reduction, minimum load balancing index and maximum voltage profile in radial distribution. PV array used as distributed generator (DG), pre identify the most candidate busses for placing PV and DSTATCOM by using voltage stability index. Then the MO-MFPA is used to reduce the size and locations of PV arrays and DSTATCOM from the selected busses. In [49] VSI is used to find the placement of D-STATCOM devices and optimal size of D-STATCOM is determined by using bat swarm optimization algorithm. In [50] 2016, Safari and Ahmad used discrete imperialistic competition \& nelder-mead algorithm to solve D-STATCOM placement problem in distribution systems, while DG's are previously installed in it. Voltage stability index (VSI) is applied to identify the weak buses in the network. Objective function is minimizing the sum of normalized active power losses and D-STATCOM installation cost. Coordination of DG's and D-STATCOM's will give better results compare to D-STATCOM's without DG's in distribution feeder. New DICA-NM hybrid algorithm is provide more accuracy compare to evolutionary methods such as GA, PSO, ACO etc.

In [51] 2015, loss sensitivity factor (LSI) and bacterial foraging optimization algorithm have been hybridized for D-STATCOM's and DG's placement in distribution system. It is used to reduce power loss and improves the voltage profile of the system. The five loss sensitivity factor values were sorted in descending order, the trial and error method is used to determine optimal location between five buses. The bus which is having least amount of power loss, that bus is selected as candidate bus for placement of DG's or D-STATCOM's.

Meta-heuristic optimization techniques are simple and easier to find optimal solution to the problems. Compare to analytical methods and Artificial Neural network based methods, Meta-heuristic methods are easy to define and used for multi objective function by considering many constraints. But this technique is suffered from premature convergence and lack of accuracy [52-57].

Sensitivity approaches are simple and most suitable for the placement problem, but it is consider only one objective problem [58-61]. Any sensitivity approach is designed to find the critical location of custom power devices/FACTS devices from a specific point of view, and it is difficult to consider many constraints for the problem. The combination of sensitivity approaches and meta-heuristic methods are mostly used to solve the problems. Sensitivity approaches are used for finding most critical nodes, to make the problem smaller. Optimization techniques can be applied to nodes, to determine the few specific nodes for the best size of custom power/FACTS devices. Using this process, there exist balance between the accuracy and speed, and it is possible to use multi objective functions and consider many constraints. Review of different research works on custom power devices/FACTS devices allocation as shown in Table 2.

Table 2. Review of Different Research Works on Custom Power Devices/FACTS Devices Allocation.

\begin{tabular}{|c|c|c|c|c|}
\hline S.no & Objectives & Devices & Algorithm & Remarks \\
\hline 1 & $\begin{array}{l}\text { Power loss reduction, Good damping } \\
\text { characteristics }\end{array}$ & $\begin{array}{l}\text { STATCOM \& } \\
\text { PSS }\end{array}$ & Genetic & $\begin{array}{l}\text { Run time, Require long revisiting of optimal } \\
\text { solutions. }\end{array}$ \\
\hline 2 & $\begin{array}{l}\text { Reactive power dispatch problem, minimum } \\
\text { transmission losses and voltage deviation }\end{array}$ & STATCOM & $\begin{array}{l}\text { Chemical } \\
\text { Reaction }\end{array}$ & $\begin{array}{l}\text { Its local search ability of is weak, It is often } \\
\text { traps into local optima }\end{array}$ \\
\hline 3 & $\begin{array}{l}\text { Overall voltage profile imprudent, system } \\
\text { load ability. }\end{array}$ & STATCOM & $\begin{array}{l}\text { Cuckoo } \\
\text { search }\end{array}$ & Difficult to Solve multi objective problems \\
\hline 4 & Minimization of power flow problems & SVC \& TCSC & $\mathrm{BF}+\mathrm{NMA}$ & Delay in reaching the global solution \\
\hline 5 & $\begin{array}{l}\text { Power loss reduction \& better voltage } \\
\text { stability margin }\end{array}$ & UPFC \& IPFC & $\mathrm{PSO}+\mathrm{GSA}$ & $\begin{array}{l}\text { Slow convergence, getting trapped in local } \\
\text { areas }\end{array}$ \\
\hline 6 & $\begin{array}{l}\text { Voltage profile enhancement, system } \\
\text { laudability improvement }\end{array}$ & STATCOM & ICA & $\begin{array}{l}\text { Required to determine total power. } \\
\text { Required more setting time. }\end{array}$ \\
\hline 7 & $\begin{array}{l}\text { Power loss reduction \& voltage profile } \\
\text { improvement }\end{array}$ & STATCOM & PSO & $\begin{array}{l}\text { Slow convergence, can't work out the } \\
\text { problem of scattering \& optimization. }\end{array}$ \\
\hline 8 & $\begin{array}{l}\text { Harmonic distortion \& voltage deviation } \\
\text { reduction }\end{array}$ & D-STATCOM & Firefly & Delay in reaching the global solution \\
\hline 9 & $\begin{array}{l}\text { Power loss reduction, voltage profile } \\
\text { improvement }\end{array}$ & D-STATCOM & Immune & Require more Computing time \\
\hline 10 & Minimum total power losses & D-STATCOM & Harmony & $\begin{array}{l}\text { Each objective function has been handled } \\
\text { separately as a single objective optimization }\end{array}$ \\
\hline
\end{tabular}




\section{CONCLUSION}

This paper has presented Meta heuristic methods, sensitive index methods and their hybrid combination for determining the optimal location and sizing of custom power devices/FACTS devices. An extensive and comprehensive survey of published literatures on this field is presented. From the analysis of comparison, it is inferred that only a fewer research work is done on distribution system compared to transmission system. There is very slight improvement in optimization techniques that are used for placement and sizing of custom power devices/FACTS devices. A comparative study on the application of different optimization techniques are done in terms of accuracy and speed. It is also concluded that for power loss minimization in power systems, most of the research has concentrated only on single device placement rather than placement of multi devices. After review of different types of meta-heuristic algorithms \& sensitivity index methods, still there is a scope for implementation of different types of new hybrid algorithms for optimal placement and sizing of custom power devices/FACTS devices in power systems.

\section{REFERENCES}

[1] Rahul Agrawal, S.K. Bharadwaj, D.P. Kothari, "Population based evolutionary optimization techniques for optimal allocation and sizing of Thyristor Controlled Series Capacitor", Journal of Electrical Systems and Information Technology, 7 February 2018

[2] A. Rezaee Jordehi, "Optimal allocation of FACTS devices for static security enhancement in power systems via imperialistic competitive algorithm (ICA)", Applied Soft Computing, vol. 48, pp. 317-328, November 2016.

[3] A. Rezaee Jordehi, "Brainstorm optimisation algorithm (BSOA): An efficient algorithm for finding optimal location and setting of FACTS devices in electric power systems", International Journal of Electrical Power \& Energy Systems, vol. 69, pp. 48-57, July 2015.

[4] Atma Ram Gupta and Ashwani Kumar, "Optimal placement of D-STATCOM using sensitivity approaches in mesh distribution system with time variant load models under load growth", Ain Shams Engineering Journal, June 2016.

[5] Acha E, Fuerte-Esquivel CR, Ambriz-Perez H, et al. FACTS: modelling and simulation in power networks. John Wiley \& Sons; 2004.

[6] Aziz Oukennou, Abdelhalim Sandali, Samira Elmoumen" Coordinated Placement and Setting of FACTS in Electrical Network based on Kalai-smorodinsky Bargaining Solution and Voltage Deviation Index" Vol. 8, No. 6, Dec 2018, pp. 4079 4088 ISSN: 2088-8708, DOI: 10.11591/ijece.v8i6.pp.4079-4088.

[7] Reza sirjani, Ahmad rezaee Jordehi, "Optimal placement and sizing of distribution static compansater in electric distribution networks: a review" Rnewable and sustainable energy reviews, Vol. 77 pp 688-694, april 2017.

[8] P. Lokender Reddy, G. Yesuratnam "A modified bacterial foraging algorithm based optimal reactive power dispatch" Vol. 13, No. 1, January 2019, pp. 361 367 ISSN: 2502-4752, DOI: 10.11591/ijeecs.v13.i1.pp361-367.

[9] Ghassan Abdullah Salman, Mohammed Hasan Ali, Ali Najim Abdullah "Implementation Optimal Location and Sizing of UPFC on Iraqi Power System Grid (132 kV) Using Genetic Algorithm” Vol. 9, No. 4, December 2018, pp. 1607 1615 ISSN: 2088-8694, DOI: 10.11591/ijpeds.v9n4.pp1607-1615.

[10] Sirote Khunkitti, Apirat Siritaratiwat "A Hybrid DA-PSO Optimization Algorithm for Multiobjective Optimal Power Flow Problems” Energies 2018, 11, 2270; doi:10.3390/en11092270.www.mdpi.com/journal/energies.

[11] S.M. Abd-Elazim and E.S. Ali, "Optimal location of STATCOM in multimachine power system for increasing loadability by Cuckoo Search algorithm", International Journal of Electrical Power \& Energy Systems, vol. 80, pp.240-251, September 2016.

[12] Sai Ram Inkollu, Venkata Reddy Kota, "Optimal setting of FACTS devices for voltage stability improvement using PSO adaptive GSA hybrid algorithm”, Engineering Science and Technology, an International Journal, vol. 19, no. 3, pp. 1166-1176, September 2016.

[13] S.M. Abd-Elazim and E.S. Ali, "Imperialist competitive algorithm for optimal STATCOM design in a multimachine power system", International Journal of Electrical Power \& Energy Systems, vol. 76, pp. 136-146, March 2016.

[14] Susanta Dutta, Provas Kumar Roy and Debashis Nandi, "Optimal location of STATCOM using chemical reaction optimization for reactive power dispatch problem", Ain Shams Engineering Journal, vol. 7, no. 1, pp. 233-247, March 2016.

[15] A. Rezaee Jordehi, "Brainstorm optimisation algorithm (BSOA): An efficient algorithm for finding optimal location and setting of FACTS devices in electric power systems", International Journal of Electrical Power \& Energy Systems, vol. 69, pp. 48-57, July 2015.

[16] ThanhLong Duong, Yao JianGang, VietAnh Truong, "Application of min cut algorithm for optimal location of FACTS devices considering system loadability and cost of installation", International Journal of Electrical Power \& Energy Systems, vol. 63, pp. 979-987, December 2014.

[17] J. Belwin Edward, N. Rajasekar, K. Sathiyasekar, N. Senthilnathan, R. Sarjila, "An enhanced bacterial foraging algorithm approach for optimal power flow problem including FACTS devices considering system loadability", ISA Transactions, vol. 52, no. 5, pp. 622-628, September 2013.

[18] Safari A, Ahmadian A and Golkar MAA, "Controller design of STATCOM for power system stability improvement using honey bee mating optimization", J Appl Res Technol, vo.11, no.1, pp.144-55, 2013.

Int J Pow Elec \& Dri Syst, Vol. 10, No. 2, June 2019: 900 - 908 
[19] Ali ES and Abd-Elazim SM, "Coordinated design of PSSs and TCSC via bacterial swarm optimization algorithm in a multimachine power system", Int J Electr Power Energy Syst, vol.36, no.1, pp.84-92, 2012.

[20] J. P. Sridhar, R. Prakash "Multi-objective whale optimization based minimization of loss, maximization of voltage stability considering cost of DG for optimal sizing and placement of DG", International Journal of Electrical and Computer Engineering (IJECE), Vol. 9, No. 2, April 2019, pp. 835 839 ISSN: 2088-8708, DOI: 10.11591/ijece.v9i2.pp.835-839.

[21] M. Laxmidevi Ramanaiah, M. Damodar Reddy "Moth Flame Optimization Method for Unified Power Quality Conditioner Allocation", International Journal of Electrical and Computer Engineering (IJECE) Vol. 8, No. 1, February 2018, pp. 530 537 ISSN: 2088-8708, DOI: 10.11591/ijece.v8i1.pp530-537.

[22] M.Lakshmi Devi, damodar Reddy "optimal unified power quality conditioner allocation in Distrnition systems for loss minimization using Gray wolf optimazation". Int. Journal of Engineering Research and Application, Vol. 7, Issue 11, (Part -3) pp.48-53, November 2017,. ISSN: 2248-9622,

[23] T Yuvaraj, KR Devabalaji "Optimal placement and sizing of DSTATCOM using garmony search algoitham" internation confirance on anltemtive energy in developing countries and emerging economices vol: 79, 2015.

[24] S. Devi and M. Geethanjali, "Optimal location and sizing determination of Distributed Generation and DSTATCOM using Particle Swarm Optimization algorithm", International Journal of Electrical Power \& Energy Systems, vol. 62, pp. 562-570, November 2014.

[25] Seyed Abbas Taher, Seyed Ahmadreza Afsari, "Optimal location and sizing of D-STATCOM in distribution systems by immune algorithm”, International Journal of Electrical Power \& Energy Systems, vol. 60, pp. 34-44, September 2014.

[26] Masoud Farhoodnea, Azah Mohamed, Hussain Shareef, Hadi Zayandeharoodi "optimal DSTATCOM placdement using firefly algorithm for power qualtiy enhancement" IEEE $7^{\text {th }}$ international powerengineering and optimizaion conference (PEOCON), 2013.

[27] Seyed abbas aher and seyed ahmadreza afsari "optimal loaction and sizing of UPQC in distribution networks using differential evolution algorithm" Hidavi publishing corporation mathematical problems in engineering 2012 .

[28] Mutegi AM, Kihato C.M \& Saulo M.J "optimal placement of FACTS devices using voltage stability indices." Annual conference on suitainable rsearch and innovation 2016

[29] m.albatsh, shmeem Ahmad "optimal placement of unified power flow controllers to improve dynamic voltage stbility using power system variable based voltage stability indices" April 2015.

[30] Muhammad nurdin, fathin saifur Rahman, "Placement of shunt VAR compensator based on senstivity analysis" June 2014vol.6.

[31] Bushra weqar, Mohd Tauseef Khan "Optimal placement of distributed generation and D-STATCOM in radial distribution network" https://doi.org/10.1080/23080477.2017.1405625.

[32] Penkita Mehta, Praghnesh Bhatta "Optimal selection of didtribution generating units and its placement for voltage stability enhancement and energy loss minimization" 2090-4479 2015 Ain Shams University. Production and hosting by Elsevier B.V.

[33] Jain A, Gupta A, Kumar A, An efficient method for D-STATCOM placement in radial distribution system; 2014. p. $1-6$.

[34] Hussain S, Visali N. "Identification of weak buses using Voltage Stability Indicator and its voltage profile improvement by using DSTATCOM in radial distribution systems", IOSR J Electr Electron Eng (IOSRJEEE), vol. 2 , no. $4 ; 2012$. p. 17-23.

[35] Saptarshi, suresh "Optimal placement of TCSC and TCPAR using sensitivity analysis" https://www.researchgate.net/publication/324173223.

[36] V.srinivasa rao,r.srinivasa rao "optimal placement of STATCOM using two stage algorithm for enhancing power system static security";PECCON-march,2017.vol:117.

[37] S.manikandan, p.arul "optimal location of multiple FACTS devices using senstivity methods"; IJETT-oct, vol.4, 2013.

[38] Fahad Iqbal, Mohd Tauseef Khan "optimal placement of Dg \& DSTATCOM for loss reduction and voltage profile improvement” Alexandria Engineering Journal, vol. 57,755-765, 2018.

[39] Atma ram gupta, ashwani kumar "Perfomance analysis of radial distribution systems with UPQC and DSTATCOM.”2016.

[40] Gupta AR, Kumar A. Optimal placement of D-STATCOM using sensitivity approaches in mesh distribution system with time variant load models under load growth. Ain Shams Eng J 2016

[41] Atma ram gupta, abhinav Jain"optimal D-STATCOM placement in radial distributin systems based on power loss index appoarch"; ICEPE-june 2015.

[42] B. Sravana Kumar, M. Suryakalavathi "Thyristor Controlled Series Compensator based Optimal Reallocation of Generators for Contingency Management" ECTI Transactions on Electrical ENG., Electronics, \& Communications VOL.16, NO.1 February 2018.

[43] Venkata padmavathi .s, saratkumar,"application of gravitationalsearch algorithm to improve power system security by optimal placement of FACTS devices".JES-2015.

[44] A.samimi, m.a.golkar "a novel method for optimal placement of FACTS based on senstivity analysis for enchancing power system static security"; Asian journal of applied science-jan.vol.5, 2012.

[45] A.parizad, a.khazali"application of HSA \& GA in optimal placement of FACTS devices considering voltage stability and losses".world acadamy of science, engineering and technology-2009.

[46] Selvaraj, Rajangam "Meta Heuristic Technique for Network Reconfiguration in Distribution system with photo voltaic and D-STATCOM" https://ieeexplore.ieee.org/xpl/RecentIssue.jsp?punumber=4082359. 
[47] Devabalaji K, Ravi K. "Optimal size and siting of multiple DG and DSTATCOM in radial distribution system using bacterial foraging optimization algorithm”. Ain Shams Eng J. vol 7(3), pp. 959-71, 2016.

[48] Babak safari, Ahmad ashouri, "optimal placement of D-TATCOM into the radial distribution networks in the presence of distributed generations". American journal of electrical and electronic engineering, .vol.4, 2016.

[49] Gupta AR, Kumar A. Energy savings using D-STATCOM placement in radial distribution system. Procedia Comput Sci, vol 70, pp. 558-64, 2015.

[50] Chatterjee A, Roy K, Chatterjee D. "A Gravitational Search Algorithm (GSA) based Photo-Voltaic (PV) excitation control strategy for single phase operation of three phase wind-turbine coupled induction generator". Energy; vol. 74. pp. 707-18, 2014.

[51] Kashani AR, Gandomi AH, Mousavi M. "Imperialistic competitive algorithm: a metaheuristic algorithm for locating the critical slip surface in 2-dimensional soil slopes". Geosci Front, vol 7(1), pp. 83-9, 2016.

[52] Lijuan W, Guohua C. Seasonal SVR with FOA algorithm for single-step and multi- step ahead forecasting in monthly inbound tourist flow. Knowl-Based Syst, vol. 110, pp. 157-66, 2016.

[53] Othman M, El-Khattam W, Hegazy Y, et al. Optimal placement and sizing of voltage controlled distributed generators in unbalanced distribution networks using supervised firefly algorithm. Int J Electr Power Energy Syst; 82:105-13, 2016.

[54] Guo L, Meng Z, Sun Y, et al. Parameter identification and sensitivity analysis of solar cell models with cat swarm optimization algorithm. Energy Convers Manag, Vol. 108, pp. 520-8, 2016.

[55] Elsisi M, Soliman M, Aboelela M, et al. "Bat inspired algorithm based optimal design of model predictive load frequency control", Int J Electr Power Energy Syst, Vol. 83, pp. 426-33, 2016.

[56] Nazari-Shirkouhi S, Eivazy H, Ghodsi R, et al. "Solving the integrated product mix- outsourcing problem using the imperialist competitive algorithm". Expert Syst Appl vol. 37(12), pp. 7615-26, 2010.

[57] Sirjani R, Mohamed A, Shareef H. "Optimal allocation of shunt Var compensators in power systems using a novel global harmony search algorithm". Int J Electr Power Energy Syst, vol. 43 no. 1, pp. 562-72, 2012.

[58] Kanwar N, Gupta N, Swarnkar A, et al. "New sensitivity based approach for optimal allocation of shunt capacitors in distribution networks using PSO". Energy Procedia; vol. 75, pp. 1153-8, 2015.

[59] Lu Z, Liu J, Liu Y, et al. "The interval sensitivity analysis and optimization of the distribution network parameters considering the load uncertainty”. Int J Electr Power Energy Syst; vol. 64, pp. 931-6, 2015.

[60] Evangelopoulos VA, Georgilakis PS, Hatziargyriou ND. "Optimal operation of smart distribution networks: a review of models, methods and future research”. Electr Power Syst Res, vol. 140, pp. 95-106, 2016.

[61] Tarôco CG, Takahashi RH, Carrano EG. Multiobjective planning of power distribution networks with facility location for distributed generation. Electr Power Syst Res, vol. 141:562-71, 2016.

Int J Pow Elec \& Dri Syst, Vol. 10, No. 2, June 2019: 900 - 908 